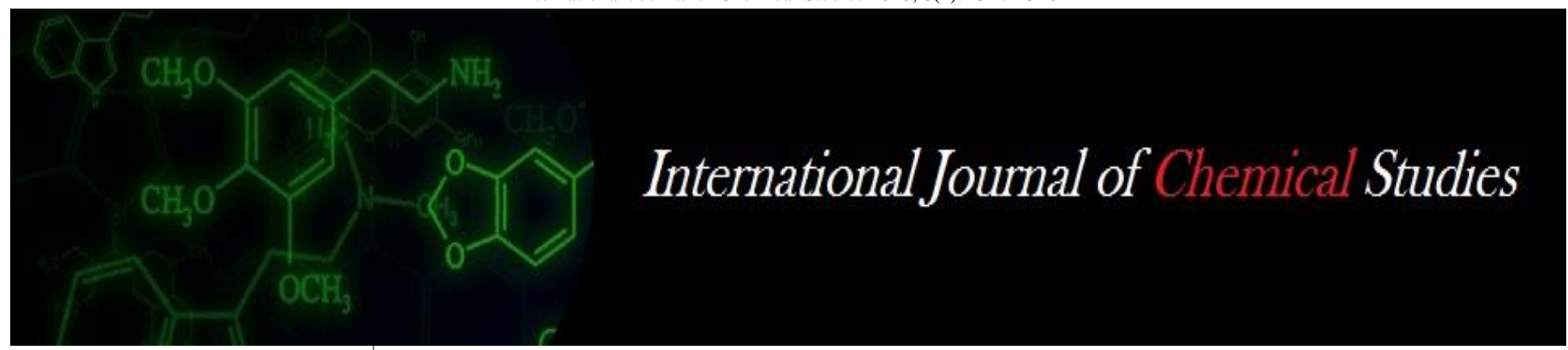

P-ISSN: 2349-8528

E-ISSN: 2321-4902

www.chemijournal.com

IJCS 2020; 8(4): 2917-2920

(C) 2020 IJCS

Received: 22-05-2020

Accepted: 26-06-2020

Sandeep Kumar Suman

Department of Agricultural

Biotechnology and Molecular

Biology, Dr. Rajendra Prasad

Central Agricultural University,

Pusa, Samastipur, Bihar, India

\section{Mithilesh Kumar}

Department of Agricultural Biotechnology and Molecular Biology, Dr. Rajendra Prasad Central Agricultural University, Pusa, Samastipur, Bihar, India

\section{Rajesh Kumar}

Department of Seed Science and

Technology, TCA, Dholi,

Muzaffarpur, Bihar, India

\section{Ajay Kumar}

Department of Plant Breeding and Genetics, Dr. Rajendra

Prasad Central Agricultural

University, Pusa, Samastipur,

Bihar, India

\section{Digvijay Singh}

Department of Plant Breeding and Genetics, Dr. Rajendra Prasad Central Agricultural University, Pusa, Samastipur, Bihar, India

\section{Avinash Kumar}

Department of Plant Breeding and Genetics, Dr. Rajendra Prasad Central Agricultural University, Pusa, Samastipur, Bihar, India
Corresponding Author: Sandeep Kumar Suman Department of Agricultural Biotechnology and Molecular Biology, Dr. Rajendra Prasad Central Agricultural University, Pusa, Samastipur, Bihar, India

\section{Assessment of genetic diversity in inbred lines of maize (Zea mays L.) and its relationship with heterosis}

\author{
Sandeep Kumar Suman, Mithilesh Kumar, Rajesh Kumar, Ajay Kumar, \\ Digvijay Singh and Avinash Kumar
}

DOI: $\underline{\text { https://doi.org/10.22271/chemi.2020.v8.i4ai.10089 }}$

\begin{abstract}
The genetic divergence among thirteen genotypes of maize were estimated by using Mahalanobis $\mathrm{D}^{2}$ statistic for ten characters. The genotypes were grouped into three clusters. Cluster I comprised 11 parental genotypes (CLQR, VL111, R4093, R6429, S8481, S8200, CML490, HK1, WLS, CLQRC and G18), while Cluster II (CLQ25) and III (CG18) were mono-genotypic. The highest inter cluster distance was recorded between cluster II and III (4.88) followed by cluster I and III (4.67). Maximum genetic distance was observed between the parents WLS and G18, whereas minimum distance was observed between the parents VL111 and S8481 suggesting more variability in genetic makeup of the genotypes included in these clusters. Cluster I comprising of 11 genotypes have maximum mean values for number of kernels per row and number of kernels row per cob while minimum mean values for plant height and ear height. Cluster II containing only CLQ25 have maximum mean values for ear girth and grain yield per plant. The highest contribution in the manifestation of total genetic divergence was exhibited by grain yield per plant $(28.63 \%)$ followed by ear girth $(28.47 \%)$, ear length $(19.23 \%)$, number of kernel per row (11.50), number of kernels row per cob (10.04). Out of 30 crosses, 11 crosses showed positive significant heterobeltiosis for grain yield per plant. The crosses CLQ25 $\times$ CLQR and WLS $\times$ R4093 belongs to high divergent class. It could be concluded that genetic diversity can be utilized as a reliable parameter for predicting heterosis in hybrids.
\end{abstract}

Keywords: genetic diversity, mahalanobis $\mathrm{d}^{2}$, genetic distance, heterobeltiosis

\section{Introduction}

Maize (Zea mays L.) is one of the oldest crop and most important food grain in the world as well as in developing countries. It is the highest yielding grain crop having multiple uses. It occupies a prominent position in global agriculture after wheat and rice. In India, maize ranks third next to rice and wheat. The nutritional qualities of maize are on par with other cereals in most of the aspects. The maize kernel contains approximately 60-70\% carbohydrates, 9-11\% crude protein, 2-3.5\% crude fiber, 3-5\% lipids and $20 \mathrm{mg}$ of $\mathrm{Ca} / 100 \mathrm{~g}$ of kernels. In any crop improvement programme, assessment of genetic diversity is an essential prerequisite for identifying potential parents for hybridization. Maize acreage and production have shown an increasing trend with the introduction of hybrids due to their high yield potential. Before hybrid development, prospective parent (inbred line) selection is a pre-requisite. Several studies on maize have shown that inbred lines from diverse stocks tend to be more productive than crosses of inbred lines from same variety (Vasal, 1998) ${ }^{[23]}$. Manifestation of heterosis usually depends on the genetic divergence of the two parental lines (Saxena et al., 1998) ${ }^{[19]}$. The quantification of genetic diversity through biometrical procedure made it possible to choose genetically diverse parents for hybrid production. Diverse parents are expected to yield higher frequency of heterotic hybrids in addition to generating a broad spectrum of variability in segregating generations. $\mathrm{D}^{2}$ analysis is a useful tool for quantifying the degree of divergence between biological population at genotypic level and in assessing relative contribution of different components to the total divergence both in intra and inter-cluster level (Murty and Arunachalam, 1966; Ram and Panwar, 1970; and Sachan and Sharma, 1971) ${ }^{[13,15,18]}$. The present study was therefore undertaken to analyze the genetic divergence of maize genotypes. 


\section{Materials method}

Thirteen genotypes of maize (Zea mays L.) were grown in Randomized Block Design with three replications at TCA, Dholi, Centre, Muzaffarpur, India, during rabi, 2017-2018. Each entry was sown in a two row of $4 \mathrm{~m}$ length. The spacing between row to row was $75 \mathrm{~cm}$ and plant to plant was $25 \mathrm{~cm}$. Observations were recorded on five randomly selected plants in each entry and in each replication for days to 50 per cent tasseling, days to 50 per cent silking, days to 50 per cent brown husk, plant height $(\mathrm{cm})$, ear height $(\mathrm{cm})$, cob girth $(\mathrm{cm})$, cob length $(\mathrm{cm})$, number of kernel rows per cob, number of kernels per row, yield per plant. The data were subjected to Mahalanobis $\mathrm{D}^{2}$ analysis. Genetic diversity was estimated as per Mahalanobis $\mathrm{D}^{2}$ statistics (Mahalanobis, 1936) ${ }^{[10]}$ and clustering of genotypes was done according to Tocher's method as described by (Rao, 1952) ${ }^{[16]}$.

\section{Results and discussion}

The genetic divergence among 13 maize genotypes was estimated for 10 characters, viz., Plant height, Ear height, days to $50 \%$ tasseling, days to $50 \%$ silking, days to $50 \%$ brown husk, ear length, ear diameter, number of kernel rows per ear, number of kernels per row, grain yield per plant. Based on this analysis, all the genotypes were grouped into three clusters on the basis of Tocher's method of clustering utilizing $\mathrm{D}^{2}$ values (Table 1.0). Cluster I comprised 11 parental genotypes (CLQR, VL111, R4093, R6429, S8481, S8200, CML490, HK1, WLS, CLQRC, G18), while Cluster II (CLQ25) and III (CG18) were monogenotypic. Similar approach was adopted earlier by various researchers (Singh and Chaudhary, 2001; More et al., 2006; Bhoite and Dumbre, 2007; Farzana et al., 2007; Alam and Alam, 2013; Singh et al., 2019) $[21,12,5,7,1,22]$. Genetic diversity is generally associated with geographical diversity, but the former is not necessarily directly related with geographical distribution. A comparison of the mean values of ten traits for different clusters showed considerable differences among them (Table 2.0). Cluster I comprising of 11 genotypes have maximum mean values for number of kernels per row and number of kernels row per cob while minimum mean values for plant height and ear height. Cluster II containing only CLQ25 have maximum mean values for ear girth and grain yield per plant. Cluster III containing only CG18 have minimum mean values for days to $50 \%$ tasseling, days to $50 \%$ silking, days to $50 \%$ brown husk while, maximum mean values for ear length. These findings are in accordance with (Singh et al., 2005; Marker and Krupakar, 2009; Alam and Alam, 2013; Singh et al., 2019; Kushwaha et al., 2020) [20, 11, 1, 22, 9]. The highest inter cluster distance (Table 3.0) was recorded between cluster II and III (4.88) followed by cluster I and III (4.67). The lowest inter cluster distance was observed between cluster I and II (4.62). The intra-cluster distance for cluster I was found 4.37 while intra-cluster distance of cluster II and
III were found zero. The genetic distance between parents (Table 4.0) varied from 2.38 to 4.89. Maximum genetic distance was observed between the parents WLS and G18, whereas minimum distance was observed between the parents VL111 and S8481. Similar findings were reported by (Farzana Jabeen et al., 2007; Nehvi et al., 2008; Singh et al., 2019; Kushwaha et al., 2020) ${ }^{[7,14,22,9]}$ in case of maize. The contribution of traits under study towards divergence is summarized in Table 5.0. The highest contribution in the manifestation of total genetic divergence was exhibited by grain yield per plant $(28.63 \%)$ followed by ear girth $(28.47 \%)$, ear length $(19.23 \%)$, number of kernel per row (11.50), number of kernels row per cob (10.04). The contribution of remaining traits in manifestation of genetic divergence was low or zero. Similar observation was recorded by (Anderson, 1957; Rao, 1952; Nehvi et al., 2008; Rigon et al., 2015; Ganesan et al., 2010; Singh et al., 2019; Kushwaha et al., 2020) $[2,16,14,17,8,22,9]$.

\section{Parental genetic diversity and its relationship with heterosis}

For choice of parents to be utilized in hybridization programme of any crop, it is believed that genetically divergent parental combinations produce hybrids of high heterotic response, though it may not be the sole factor. Besides, a few parents over a series of cross combinations may produce better $F_{1}$ 's, while certain combinations do relatively better or worse than would be expected on the basis of average performance of genotypes involved. Study of Table 6.0 indicated that majority of crosses belong to moderate divergence class. The cross CLQ25 × R4093, CML490 $\times$ VL111 and HK1 $\times$ VL111 exhibited significant better parent heterosis for maximum number of traits including plant height, days to $50 \%$ brown husk, ear length, number of kernels per row and grain yield per plant by CLQ25 $\times$ R4093 while, days to $50 \%$ brown husk, ear length, ear girth, number of kernels per row and grain yield per plant by CML490 × VL111 and HK1 × VL111. CLQ25 × R4093 and CML490 $\times$ VL111 belongs to moderate divergence class while, HK1 $\times$ VL111 belongs to low divergence class. This suggests the accumulation of favorable alleles in parents and when they came in hybrid combination given superior performance even in low divergence.

Study of Table 7.0 showed that out of 30 crosses, 11 crosses showed positive significant heterobeltiosis for grain yield per plant. The crosses CLQ25 $\times$ CLQR and WLS $\times$ R4093 belongs to high divergent class, CLQ25 $\times$ R4093, CG18 $\times$ R4093, CML490 $\times$ CLQR and CML490 $\times$ VL111 belongs to moderate divergence class while, R6429 $\times$ R4093, S8481 $\times$ CLQR, S8200 × CLQR, HK1 $\times$ VL111, and CLQRC $\times$ VL111 belongs to low divergence class. Similar approach was adopted earlier (Arunachalam et al. (1983); Banu et al., (2006); Fan et al., (2004); ${ }^{[3,4,6] .}$

Table 1: Clustering pattern of 13 inbred lines on the basis of $D^{2}$ statistics

\begin{tabular}{|c|c|c|}
\hline Cluster & Number of Genotypes within cluster & Genotypes in cluster \\
\hline I & 11 & CLQR, VL111, R4093, R6429, S8481, S8200, CML490, HK1, WLS, CLQRC, G18 \\
\hline II & 1 & CLQ25 \\
\hline III & 1 & CG18 \\
\hline
\end{tabular}

Table 2: Cluster mean for various traits:

\begin{tabular}{|c|c|c|c|c|c|c|c|c|c|c|}
\hline & PH & EH & DFT & DFS & DFBH & EL & EG & NKPR & NKRPC & GY \\
\hline Cluster I & 123.5576 & 61.6545 & 81.9091 & 85.4545 & 118.0909 & 9.9697 & 13.0364 & 15.4848 & 11.7576 & 4.6479 \\
\hline Cluster II & 147.6000 & 73.3667 & 84.0000 & 86.3333 & 123.3333 & 10.2333 & 15.2333 & 14.6667 & 10.6667 & 5.4933 \\
\hline Cluster III & 124.5000 & 61.8333 & 81.6667 & 85.3333 & 115.6667 & 11.2000 & 14.3333 & 14.6667 & 10.0000 & 5.2633 \\
\hline
\end{tabular}


Table 3: Mean intra and inter cluster distance $\left(D^{2}\right)$ among three clusters:

\begin{tabular}{|c|c|c|c|}
\hline & Cluster I & Cluster II & Cluster III \\
\hline Cluster I & 4.37 & & \\
\hline Cluster II & 4.62 & 0.00 & 0.00 \\
\hline Cluster III & 6.67 & 4.88 & \\
\hline
\end{tabular}

Table 4: Genetic distance between parents

\begin{tabular}{|c|c|c|c|c|c|c|c|c|c|c|c|c|}
\hline & CLQR & CLQ25 & VL111 & CG18 & R4093 & R6429 & S8481 & S8200 & CML490 & HK1 & WLS & CLQRC \\
\hline CLQ25 & 4.87 & & & & & & & & & & & \\
\hline VL111 & 4.66 & 4.62 & & & & & & & & & & \\
\hline CG18 & 4.83 & 4.88 & 4.48 & & & & & & & & & \\
\hline R4093 & 4.48 & 4.67 & 4.13 & 4.74 & & & & & & & & \\
\hline R6429 & 4.52 & 4.52 & 3.55 & 4.59 & 4.20 & & & & & & & \\
\hline S8481 & 3.76 & 4.05 & 2.38 & 4.29 & 4.54 & 4.30 & & & & & & \\
\hline S8200 & 4.08 & 4.37 & 3.87 & 4.47 & 4.83 & 3.56 & 4.35 & & & & & \\
\hline CML490 & 4.54 & 4.67 & 4.61 & 4.65 & 4.73 & 3.68 & 3.77 & 4.70 & & & & \\
\hline HK1 & 4.85 & 4.81 & 4.37 & 4.81 & 4.41 & 4.76 & 4.00 & 3.91 & 4.28 & & & \\
\hline WLS & 4.50 & 4.68 & 4.29 & 4.73 & 4.88 & 4.04 & 4.36 & 4.84 & 4.81 & 4.37 & & \\
\hline CLQRC & 4.77 & 4.81 & 4.19 & 4.86 & 4.65 & 4.78 & 4.43 & 4.28 & 4.40 & 4.84 & 4.59 & \\
\hline G18 & 4.57 & 4.73 & 4.45 & 4.75 & 4.85 & 4.02 & 4.20 & 4.79 & 4.86 & 4.42 & 4.89 & 4.58 \\
\hline
\end{tabular}

Table 5: Contribution percentage of different traits towards total divergence:

\begin{tabular}{|c|c|c|}
\hline S. No. & Source & Contribution \% \\
\hline 1 & Plant height $(\mathrm{cm})$ & 0.03 \\
\hline 2 & Ear height $(\mathrm{cm})$ & 0.01 \\
\hline 3 & Days to 50\% Tasseling & 0.24 \\
\hline 4 & Days to 50\% Silking & 0.78 \\
\hline 5 & Days to 50\% brown husk (days) & 19.23 \\
\hline 6 & Ear length $(\mathrm{cm})$ & 28.47 \\
\hline 7 & Ear girth $(\mathrm{cm})$ & 11.50 \\
\hline 8 & Number of kernel per row & 10.04 \\
\hline 9 & Number of kernels row per cob & 28.63 \\
\hline
\end{tabular}

Table 6: Relationship between parental diversity and heterosis in $F_{1}$ crosses

\begin{tabular}{|c|c|c|c|c|c|c|}
\hline S No & Crosses & Number of characters for which the $F_{\text {I }}$ was heterotic & Cluster to & rents belong & $D^{2}$-value & Divergence class \\
\hline & & & Line & Tester & & \\
\hline & CLQ25 × CLQR & 4 & II & I & 4.87 & High \\
\hline & CLQ25 × VL111 & 3 & II & I & 4.62 & Moderate \\
\hline & CLQ25 × R4093 & 5 & II & $\mathrm{I}$ & 4.67 & Moderate \\
\hline & CG18 $\times$ CLQR & 2 & III & $\mathrm{I}$ & 4.83 & Moderate \\
\hline & CG18 $\times$ VL111 & 2 & III & I & 4.48 & Moderate \\
\hline & CG18 × R4093 & 2 & III & $\mathrm{I}$ & 4.74 & Moderate \\
\hline & R6429 × CLQR & 2 & $\mathrm{I}$ & I & 4.52 & Moderate \\
\hline & R6429 × VL111 & 4 & $\mathrm{I}$ & $\mathrm{I}$ & 3.55 & Low \\
\hline & R6429 × R4093 & 3 & $\mathrm{I}$ & $\mathrm{I}$ & 4.20 & Low \\
\hline & S8481 × CLQR & 4 & I & I & 3.76 & Low \\
\hline & S8481 $\times$ VL111 & 4 & $\mathrm{I}$ & $\mathrm{I}$ & 2.38 & Low \\
\hline & $\mathrm{S} 8481 \times \mathrm{R} 4093$ & 4 & $\mathrm{I}$ & $\mathrm{I}$ & 4.54 & Moderate \\
\hline & S8200 × CLQR & 4 & $\mathrm{I}$ & $\mathrm{I}$ & 4.08 & Low \\
\hline & S8200 $\times$ VL111 & 4 & I & I & 3.87 & Low \\
\hline & $\mathrm{S} 8200 \times \mathrm{R} 4093$ & 4 & $\mathrm{I}$ & $\mathrm{I}$ & 4.83 & Moderate \\
\hline & CML490 × CLQR & 3 & $\mathrm{I}$ & $\mathrm{I}$ & 4.54 & Moderate \\
\hline & CML490 $\times$ VL111 & 5 & I & I & 4.61 & Moderate \\
\hline & CML490 × R4093 & 3 & $\mathrm{I}$ & $\mathrm{I}$ & 4.73 & Moderate \\
\hline & HK1 $\times$ CLQR & 4 & $\mathrm{I}$ & $\mathrm{I}$ & 4.85 & High \\
\hline & HK1 $\times$ VL111 & 5 & $\mathrm{I}$ & $\mathrm{I}$ & 4.37 & Low \\
\hline & HK1 $\times$ R4093 & 4 & $\mathrm{I}$ & $\mathrm{I}$ & 4.41 & Low \\
\hline & $\mathrm{WLS} \times \mathrm{CLQR}$ & 3 & $\mathrm{I}$ & $\mathrm{I}$ & 4.50 & Moderate \\
\hline & WLS $\times$ VL111 & 4 & $\mathrm{I}$ & $\mathrm{I}$ & 4.29 & Low \\
\hline & WLS $\times$ R4093 & 3 & $\mathrm{I}$ & $\mathrm{I}$ & 4.88 & High \\
\hline & $\mathrm{CLQRC} \times \mathrm{CLQR}$ & 3 & $\mathrm{I}$ & $\mathrm{I}$ & 4.77 & Moderate \\
\hline & CLQRC $\times$ VL111 & 4 & I & I & 4.19 & Low \\
\hline & CLQRC $\times$ R4093 & 3 & $\mathrm{I}$ & $\mathrm{I}$ & 4.65 & Moderate \\
\hline & $\mathrm{G} 18 \times \mathrm{CLQR}$ & 3 & $\mathrm{I}$ & $\mathrm{I}$ & 4.57 & Moderate \\
\hline & G18 $\times$ VL111 & 3 & $\mathrm{I}$ & $\mathrm{I}$ & 4.45 & Moderate \\
\hline & $\mathrm{G} 18 \times \mathrm{R} 4093$ & 3 & $\mathrm{I}$ & $\mathrm{I}$ & 4.85 & High \\
\hline
\end{tabular}


Table 7: Divergence classes of crosses exhibiting positive significant heterobeltiosis for grain yield per plant

\begin{tabular}{|c|c|c|c|}
\hline Sl. No. & Crosses & Heterobeltiosis & Divergence class \\
\hline 1 & CLQ25 $\times$ CLQR & $182.38^{* *}$ & High \\
\hline 2 & CLQ25 $\times$ R4093 & $176.60^{* *}$ & Moderate \\
\hline 3 & CG18 $\times$ R4093 & $175.59^{* *}$ & Moderate \\
\hline 4 & R6429 $\times$ R4093 & $204.74^{* *}$ & Low \\
\hline 5 & S8481 $\times$ CLQR & $167.18^{* *}$ & Low \\
\hline 6 & S8200 $\times$ CLQR & $118.27^{*}$ & Moderate \\
\hline 7 & CML490 $\times$ CLQR & $186.06^{* *}$ & Moderate \\
\hline 8 & CML490 $\times$ VL111 & $215.89^{* *}$ & Low \\
\hline 9 & HK1 $\times$ VL111 & $176.19^{* *}$ & High \\
\hline 10 & WLS $\times$ R4093 & $179.83^{* *}$ & Low \\
\hline 11 & CLQRC $\times$ VL111 & $155.74^{* *}$ & \\
\hline
\end{tabular}

\section{Conclusion}

Genetic diversity analysis was done to find out diverse inbred lines in maize, Genetically diverse parents might be utilized in breeding programme to get heterotic individuals. Thirteen maize inbred lines were clustered into three clusters. The crosses involving parents/inbred lines from most divergent clusters are expected to manifest maximum heterosis and generate wide variability in genetic architecture. Based on the quantitative data, the inbred lines were clustered into three cluster A, B and C. Cluster A accommodated 11 inbred lines namely CLQR, VL111, R4093, R6429, S8481, S8200, CML490, HK1, WLS, CLQRC, G18, while cluster B and C consisted of single inbred lines CLQ25 and CG18, respectively. Majority of crosses belong to moderate divergence class. The cross CLQ25x R4093, CML490 x VL111 and HK1 x VL111 showed heterosis for maximum number of five characters, having $\mathrm{D}^{2}$ value $4.67,4.61$ and 4.37, respectively.

\section{Acknowledgement}

Authors would like to thanks, Department of Plant Breeding \& Genetics, Tirhut College of Agriculture, Dholi for providing necessary help, financial support and other technical inputs during the course of field trial.

\section{References}

1. Alam MS, Alam MF. Genetic divergence study of maize inbred lines (Zea mays L.). International Journal of Sustainable Agricultural Technology. 2013; 5(3):28-31.

2. Anderson E. A semi graphical method for the analysis of complex problems. Perspectives in Mathematics Academy of Sciences. Washington. 1957; 43:923-927.

3. Arunachalam V, Bandyopadhyay A, Nigam SN, Gibbons RW. Heterosis in relation to genetic divergence and specific combining ability in groundnut (Arachis hypogaea L.). Euphytica. 1983; 33:33-39.

4. Banu MR, Muthaiah AR, Ashok S. Combining ability studies in pigeonpea. Crop Research. 2006; 31(3):396398.

5. Bhoite KD, Dumbre AD. Studies on genetic diversity in forage maize (Zea mays L.). Journal of Maharashtra Agricultural Universities. 2007; 32(2):290-291.

6. Fan XM, Tan J, Yang JY, Chen HM. Combining ability and heterotic grouping of ten temperate subtropical and tropical quality protein maize inbreds. Maydica. 2004; 49:267-272.

7. Farzana, Jabeen, Sahib KH, Satyanarayana E. Divergence studies in quality protein maize (Zea mays L.) genotypes. Research on Crops. 2007; 8(3):609-611.

8. Ganesan KN, Nallathambi G, Thura SN, Tamilarasi PM. Genetic divergence analysis in indigenous maize germplasms (Zea mays L.). Electronic Journal of Plant Breeding. 2010; 1(4):1241-1243.
9. Kushwaha N, Ravi Kant, Kumar R, Nilanjaya Chhaya R, Sinha N, Singh D et al. Study of Genetic Divergence in Lowland Rice Genotypes of Bihar. International Journal of Current Microbiology and Applied Science. 2020; 9(02):88-94.

10. Mahalanobis PC. On the generalized distance in statistics Proceedings of Natural Institute of Science. 1936; 2:4955.

11. Marker S, Krupakar A. Genetic divergence in exotic maize germplasm (Zea mays L.). Journal of Agricultural and Biological Science. 2009; 4(4):44-47.

12. More AJ, Bhoite KD, Pardeshi SR. Genetic diversity studies in forage maize (Zea mays L.). Research on Crops. 2006; 7(3):728-730.

13. Murty BR, Arunachalam V. The nature of divergence in relation to breeding system in crop plants. Indian Journal of Genetics. 1966; 26A:188-198.

14. Nehvi FA, Makhdoomi MI, Vaseem, Yousuf, Bahar FA. Sabeena Genetic divergence among local maize (Zea mays L.) cultivars of Kashmir Valley. Journal of Eco friendly Agriculture. 2008; 3(2):130-133.

15. Ram J, Panwar DVS. Interspecific divergence in rice (Oryza sativa L.) Indian Journal of Genetics. 1970; 30:12.

16. Rao CR. Advanced statistical methods in biometrical research. John Willy and Sons, New York, 1952.

17. Rigon JPG, Capuani S, Rigon CAG. Genetic divergence among maize hybrids by morphological descriptors. Bragantia. 2015; 74(2):156-160.

18. Sachan KS, Sharma JR. Multivariate analysis of divergence in tomato. Indian Journal of Genetics. 1971; 31:86-93.

19. Saxena VK, Mathi NS, Singh NN, Vasal SK. Heterosis in maize: Grouping and patterns. Proc. of 7th Asian Regional Maize Workshop. Los Banos, Philippines. 1998; 23-27, 124-133.

20. Singh P, Sain D, Dwivedi VK, Kumar Y, Sangwan O. Genetic divergence studies in maize (Zea mays L.). Annals of Agri Bio Research. 2005; 10(1):43-46.

21. Singh PK, Chaudhari LB. Genetic divergence in maize (Zea mays L.). Journal of Research - Birsa Agricultural University. 2001; 13(2):193-196.

22. Singh D, Kumar A, Kumar R, Kushwaha N, Mohanty T, Kumari P. Genetic diversity analysis of QPM (Zea mays L.) inbreds using morphological characters. Journal of Pharmacognosy and Phytochemistry. 2019; 9(1):12051210.

23. Vasal SK. Hybrid maize technology: Challenges and expanding possibilities for research in the next century. Proc. of $7^{\text {th }}$ Asian Regional Maize Workshop. Los Banos, Philippines. 1998; 23-27, 58-62. 